\begin{abstract}
AnNa Warda
Uniwersytet Łódzki, Wydział Filologiczny, Instytut Rusycystyki, Zakład Literatury i Kultury Rosyjskiej (Łódź, Polska)
\end{abstract}

\title{
Semantyka ogrodu w poemacie opisowym Stiepana Dżunkowskiego pt. Dacza Aleksandra
}

Poemat opisowy Stiepana Dżunkowskiego pt. Dacza Aleksandra, ogród zabawowy Jego Imperatorskiej Wysokości, świątobliwego monarchy i Wielkiego księcia Aleksandra Pawłowicza (Александрова дача, увеселительный сад Его императорского Высочества благоверного государя и Великого князя Александра Павловича) napisany w $1793 \mathrm{r}$. jest przykładem utworu literackiego na temat ogrodu, założonego na podstawie wcześniejszej narracji, do której ogród ten nawiązywał poprzez odwołujące się do niej znaki. Powstałe w wyniku tego relacje intertekstualne wpisane zostały zarówno w ogród, jak też w dzieło powstałe po jego stworzeniu (Kaczmarczyk 2011: 41-58). Ogród opisany w poemacie był swego rodzaju medium narracji, poprzez dostarczenie odbiorcy określonych bodźców oraz przedstawienie mu różnego rodzaju znaków w określonej kolejności i czasie.

Autor wspomnianego poematu - Stiepan Dżunkowski (1762-1839), podobnie jak wielu innych twórców osiemnastego stulecia, zajmował się pisaniem w czasie wolnym od innych zawodowych obowiązków (był tajnym radcą, ekonomistą, agronomem, tłumaczem). Z rozkazu Katarzyny II został w młodości oddelegowany w celach edukacyjnych do Anglii; odwiedził też Francję i Flandrię, a po powrocie do Rosji w roku 1792 caryca mianowała go nauczycielem języka angielskiego wielkich książąt. Wtedy właśnie napisał poemat, który był jego debiutem literackim (Словарь... 1988: 262-263). Równolegle z rosyjskim tekstem ukazał się jego przekład na język francuski, który doczekał się aż trzech wydań w tym języku $(1793,1794,1804)$. Rosyjskie wydania utworu były ilustrowane rycinami artysty podpisującego się inicjałami I. G., które zostały wykonane na podstawie akwarel Gawriły Siergiejewa (Выжевский 2011).

Opisana w utworze dacza Aleksandra była budowana w latach osiemdziesiątych XVIII w. (ukończona w 1789 r.) na polecenie Katarzyny II pod Pawłowskiem, dla małoletniego wnuka carycy - wielkiego księcia Aleksandra. Angielski park, który otaczał daczę, był wizualną ilustracją do napisanej przez władczynię 
w roku 1781 Bajki o carewiczu Chlorze przeznaczonej właśnie dla Aleksandra. Jej moralistyczna formuła wpłynęła niewątpliwie na to, że w zaprojektowanym na jej podstawie ogrodzie dominującą rolę pełniły kategorie etyczne. Droga wiodąca przez ogród przebiegała wzdłuż kilkunastu pawilonów, mostków, zapory na rzece Tyzwie, groty ze stawem itp., które rozwijały główne wątki bajki, nawiązywały do jej epizodów, a także do samej Katarzyny II i jej rządów oraz motywów architektonicznych europejskich parków krajobrazowych.

Zarówno losy samego zabytku architektonicznego, powstałego na motywach bajki Katarzyny II, jak też związanej z nim dokumentacji, potoczyły się w bardzo niefortunny sposób, ponieważ ani jedno, ani drugie nie przetrwało do naszych czasów. Nie ma również pewności co do tego, kto był faktycznym autorem projektu. Bierze się pod uwagę trzy nazwiska: Charles'a Camerona - ulubionego architekta Katarzyny II (Краснов 2005: 247-248), znanego architekta i pisarza Nikołaja Lwowa oraz Andrieja Samborskiego - nauczyciela księcia Aleksandra (Словарь... 1988: 263).

Pomysł wybudowania kompleksu architektoniczno-pejzażowego mającego dydaktyczny charakter Katarzyna II przejęła najprawdopodobniej od Piotra I, chociaż tradycja ogrodów w Rosji sięga jeszcze XVI wieku (Веселова 2010: 356-403; Лазарчук 2010: 325-355; Lichaczow 1991). Piotr I zapełniał swoje petersburskie ogrody dużą liczbą ,znaczących” obiektów, nadając im tym samym charakter placówki dydaktycznej (Lichaczow 1991: 120). Właśnie za jego panowania sztuka ogrodowo-parkowa nabrała „europejskiego”, oświeceniowego charakteru. Ogród Letni Piotra był swego rodzaju „akademią”, w której przedstawiciele rosyjskiego społeczeństwa przyswajali początki wykształcenia europejskiego. W jego części, a także w ogrodzie peterhofskim i ogrodzie w Carskim Siole Piotr I urządził labirynt, nawiązujący do labiryntu wersalskiego oraz obrazu życia ludzkiego, ukazanego w przypowieściach Ezopa. Ogrody te nauczały języka emblematów i symboli (Lichaczow 1991: 121). Co istotne, obok „oświecicielskiej" funkcji miejsca te zachowały również rozrywkowy charakter, znamienny dla holenderskiego baroku. Piotra interesowały, na przykład, różnego rodzaju żarty ogrodowe sprawiające przyjemność i zaskakujące przebywających w nim gości (np. „wodne kurioza” pryskacze, zabawne fontanny, strzeleckie sztuczki (Lichaczow 1991: 123). W carskich ogrodach znajdowały się również, wzorem ogrodów moskiewskich i holenderskich, „samotne zakątki”, altanki, groty, boskiety, treliaże, gięte alejki, ale także pałace letnie, ptaszarnie i zwierzyńce (Lichaczow 1991: 125-126).

Kompleks architektoniczno-pejzażowy wniesiony dla Aleksandra stanowił syntezę ogrodu czasów Piotra I, pełniącego funkcję dydaktyczno-oświecicielskią i rozrywkową z nowym obliczem parku angielskiego charakterystycznego dla końca XVIII wieku. Był on ulokowany na brzegu Tyzwy, dopływie rzeki Sławianki, i w zamierzeniu miał stanowić ilustrację do bajki Katarzyny II o carewiczu Chlorze i jego poszukiwaniach róży bez kolców. Wędrówka po kompleksie 
prowadziła obok różnych budowli i miejsc znanych z bajki Katarzyny II, a także odwołujących się do tradycji klasycznych angielskich parków krajobrazowych.

Książę Aleksander i jego brat Konstanty oraz sama Katarzyna (zajęta wojną ze Szwecją i Turcją) nie odwiedzali zbyt często wybudowanego przez nią zespołu architektoniczno-parkowego, a po zaręczynach Aleksandra z Luizą-Marią Augustą Badeńską w 1793 r. dacza Aleksandra przestała odgrywać jakąkolwiek rolę w życiu księcia. Od początku XIX w. kompleks zaczął powoli podupadać, wyposażenie domu Aleksandra po dojściu Pawła do władzy najprawdopodobniej zostało przewiezione do pobliskiego parku w Pawłowsku i umieszczone tam w pałacu Aleksandra rozbudowanym w latach 1797-1798 (Выжевский: 2011). W ciągu kolejnych lat pozostałe budowle popadały w ruinę i do dziś zachowały się jedynie zniszczone resztki świątyni Flory i Pomony ${ }^{1}$.

Pomysłodawcą utworu opisującego to niezwykłe miejsce był najprawdopodobniej protojerej Samborski, przyjaciel ojca Dżunkowskiego, spowiednik Pawła I i nauczyciel prawa wielkich książąt (Словарь... 1988: 262). Nim przejdę do omówienia opisanego w poemacie Dżunkowskiego ogrodu i zakodowanych w nim narracji korespondujących z bajką Katarzyny II o carewiczu Chlorze, przypomnę krótko jej treść. W odległych czasach, jeszcze przed powstaniem Rusi Kijowskiej żył car, który był prawym, dobrym, życzliwym władcą, dbającym o swych poddanych. Miał kochającą żonę, która urodziła mu syna o imieniu Chlor. Świętowanie narodzin carewicza zostało niespodziewanie przerwane wieścią o napaści wroga na ziemie cara, który wraz z żoną zostawił biesiadników i w asyście drużyny wyruszył bronić swego kraju. Podczas nieobecności rodziców carewicz wyrósł na chłopca o niespotykanej bystrości umysłu oraz inteligencji. Wieści o nim dotarły nawet do chana kirgiskiego, który porwał chłopca, by sprawdzić ich wiarygodność. W tym celu zlecił mu znalezienie w ciągu trzech dni róży bez kolców będącej symbolem cnoty. Niezbędnych rad udzieliła carewiczowi córka chana - Felica. Wysłała też z nim swego syna o imieniu Rozsądek, który pomagał Chlorowi w jego wyborach oraz wspierał go, gdy ten ulegał pokusom (np. grzesznym rozrywkom, leniwemu, konsumpcyjnemu życiu w posiadłości murzy Lenia, czy też komplementom fałszywych pochlebców, którzy chcieli zawrócić go z właściwej drogi). Podczas wędrówki chłopcy dotarli do wiejskiej chaty, której gospodarze, życzliwi i pracowici chłopi, suto ich ugościli i z niezwykłym szacunkiem wypowiadali się o odwiedzającej ich domostwo Felicy. Po wielu zmaganiach z trudnościami zewnętrznymi oraz własną słabością Chlor zdobył różę bez kolców i powrócił do domu.

Jak już wspominaliśmy, utwór Dżunkowskiego jest poematem opisowym (Warda 2003: 196-197), z którym ten zapoznał się najprawdopodobniej podczas

Kompleks parkowo-pałacowy carewicza Aleksandra został wspomniany w książce I. G. Georgi Описание российско-императорского столичного города Санкт-Петербрга и достопамятностей в окрестностях оного, с планом (1794). Pierwsze niemieckie wydanie tej książki Georgi ukazało się w 1791 r. 
swojego siedmioletniego pobytu w Anglii (gatunek ten pojawił się Rosji w latach osiemdziesiątych wieku XVIII za sprawą francuskich i niemieckich przekładów Czterech pór roku (1726-1730) Jamesa Thomsona). Przypomnijmy, że poemat opisowy to dłuższy utwór wierszowany, którego świat przedstawiony konstytuowany jest głównie przez motywy statyczne. Zasadniczą formę wypowiedzi stanowi w nim opis. Tematyka obejmuje najczęściej zjawiska przyrody, życie wiejskie, prace rolnicze, krajobrazy, zabytki kultury itp. Opisowość jest tu połączona z dydaktyzmem, elementami dyskursu filozoficznego lub tendencją panegiryczną (Stownik... 1996: 366).

W poemacie S. Dżunkowskiego opisany został dość szczegółowo zespół parkowo-pałacowy daczy Aleksandra, a w dygresjach lirycznych autor poruszył problem kontynuacji idei Piotra I przez Katarzynę II, oświeconą monarchinię. Utwór napisany został bardzo rzadkim w poezji rosyjskiej XVIII wieku pięciostopowym jambem.

Opis ogrodu poprzedza apostrofa do muz, w której podmiot liryczny nawiązując do wieloletniego pobytu autora poematu w Anglii i posługując się znaną w starożytności nazwą wyspy - Albion, wypowiada się z uznaniem o jego wielowiekowym rozwoju, konsekwentnie realizowanej edukacji obywateli, rozważnie prowadzonej gospodarce rolnej, poszanowaniu natury oraz umiejętności łączenia przez mieszkańców wyspy przyjemnego z pożytecznym (Warda 2010: 17-22). Pochwała życia w Anglii jest tu jednak tylko przyczynkiem do mającej dalej miejsce afirmacji Rosji i jej władczyni - Felicy, dzięki której Rosja - jak metaforycznie zauważył podmiot mówiący, z chłopca przekształciła się w olbrzyma.

W opisowej części utworu podmiot liryczny odwołując się do znanej jeszcze z okresu Starej Rusi, a także zachodnioeuropejskiego Średniowiecza (Szczukin 2006: 72-75) asocjacji ogrodu z rajem, mówi, że Bóg na miejsce raju wybrał właśnie Rosję, w której są wszelkie bogactwa i piękna przyroda. Tu właśnie docierają z innych krajów nauki, a Rosjanie mają swój Nil i Eufrat, czyli Newę. Kobieca ręka Felicy przeistoczyła przyrodę północy w ziemski raj, czyli ogród Aleksandra. Przyszły władca Rosji kroczy jej śladem i kształtuje swą osobowość poznając losy Chlora przedstawione w ogrodzie. Są w nim piękne, cieniste aleje, niezwykła przyroda i wspaniałe osobliwości architektury. Dominantą utworu Dżunkowskiego nie są jednak opisy przyrody, lecz zgromadzone w ogrodzie osobliwości architektury i sztuki, które mają świadczyć o wielkości Rosji i odzwierciedlać prawdziwe oblicze carycy oraz jej bliskich.

Przedstawiony w poemacie angielski ogród otaczający posiadłość Aleksandra miał charakter wizualnej metafory, w której pozornie niespójne elementy były logiczną strukturą, mającą określone znaczenia. Dla osób nie znających bajki o Chlorze budowle architektoniczne znajdujące się w ogrodzie pod Pawłowskiem były jedynie godnymi podziwu budowlami. Ich semantyka stawała się zrozumiała dopiero dla tych, którzy zapoznali się z jej treścią. 
Podróż edukacyjna po parku opisanym w poemacie Dżunkowskiego rozpoczynała się od opisu znajdującego się wśród drzew i kwiatów pałacu - namiotu chana kirgiskiego uwieńczonego złotą kopułą:

\section{В усыпанном вокруг цветами поле}

Над берегом крутым воздвижен дом;

Как у Киргизских рек на злачном доле,

Поставлен со златым шатер верхом. (Джунковсий 1793).

Idąc dalej na zachód (kierunek kojarzony w starożytności z krainą umarłych, w judaizmie i chrześcijaństwie - miejscem, gdzie umiera nie tylko słońce, ale też człowiek duchowy i rozumny), drogą krótką, prostą i pełną kwiatów można było dotrzeć do pełnego przepychu obiektu architektonicznego - pawilonu murzy Lenia. To piękne miejsce jest, jak podkreśla podmiot liryczny, niebezpieczne dla młodych ludzi, ponieważ powoduje u nich leniwą i bierną postawę życiową. W bajce Katarzyny mieszkańcy pałacu wraz z jego właścicielem prowadzili konsumpcyjny styl życia i zniechęcali Chlora do dalszych poszukiwań.

$\mathrm{Z}$ przepychem tego pawilonu kontrastowała znajdująca się w niedalekiej odległości od niego chatka chłopska, wokół której - podobnie jak w bajce - rozciągało się pokryte zbożem pole. Miejsce to, jak czytamy w poemacie Dżunkowskiego, symbolizowało pracowitość i harmonię. Dygresja na temat stanu chłopskiego, jego szlachetności, pracowitości i uczciwości nie byłą przypadkowa. Dżunkowski bowiem był członkiem Wolnego Towarzystwa Ekonomicznego, pracował nad podręcznikiem na temat racjonalnych metod prowadzenia gospodarstwa rolnego, był autorem wielu artykułów na temat rozwoju rolnictwa, przedsiębiorczości, zamiany pańszczyzny na czynsz (Словарь...1988: 262). Przed chatą chłopską leżał ogromny głaz z wyrytym na nim napisem: „Chroń złote kamienie”, który symbolizował Prawo, czyli Nakaz Katarzyny, sporządzony dla potrzeb tzw. Komisji Karnej (1767 r.). W jej skład wchodzili deputaci, mający opracować kodeks prawny dla Imperium. W miejscu tym schowana była, jak w arce, symboliczna złota księga symbolizująca ów Nakaz.

Od chatki chłopskiej droga prowadziła dalej do świątyni, poświęconej rzymskiej bogini wegetacji i urodzajów - Cererze. Tym samym obecny w bajce wątek chłopski został rozbudowany przez odwołanie się do tradycji antycznej wykorzystywanej właśnie w parkach angielskich. To właśnie miejsce preferował wnuk Felicy - Aleksander, dając tym samym wyraz swej więzi ze stanem chłopskim.

Dalsza wędrówka po ogrodzie prowadziła w kierunku źródła nimfy Egerii², będącej symbolem kobiety-doradcy, powiernicy. Miejsce to było poświęcone przez Pawła jego żonie - Marii Fiodorownie. W pobliżu źródła znajdowała się

Egeria - rzymska bogini albo nimfa. Miała być powiernicą, doradczynią i żoną albo przyjaciółką Numy Pompilusza; przen. inspiratorka, doradczyni, powiernica, towarzyszka duchowa męża stanu, artysty. 
się grota, do której zgodnie z mitem, chodził Numa Pompiliusz, by zwierzać się Egerii i uzyskiwać od niej rady. W tym miejscu bohater liryczny czyni dygresję, że Rosja również ma swoje własne bóstwo - Felicę, do której po poradę mogą zwracać się inni władcy, doceniający jej dobroć, umiejętność przewidywania przyszłości, praworządność i wielkość.

Najważniejszą z punktu widzenia bajki Katarzyny budowlą ogrodu pod Pawłowskiem była Świątynia róży bez kolców (Сазонова 2006: 524-557; Lichaczow 1991: 40-41; Marecki, Rotter 2007). Była ona, zgodnie z treścią bajki, ulokowana na szczycie wzniesienia, na które dojść można było stromą, kamienistą drogą. Świątynia zbudowana była na planie koła, wsparta na siedmiu kolumnach, pośrodku zaś znajdował się ołtarz, na którym w błękitnej donicy rosła róża bez kolców. Podmiot liryczny porównuje wędrówkę do Świątyni róży bez kolców z księgą, która uczy młodych ludzi, jak być cnotliwym, żyć dla innych, nie czynić zła, dążyć z uporem i mądrością do szczęścia. Jak czytamy w poemacie Dżunkowskiego, na sklepieniu świątyni namalowany był wizerunek Piotra I, który z wieczności patrzył na szczęśliwą, zamożną i potężną Rosję. Portret Katarzyny II umieszczony był na tarczy, o którą wspierał się Piotr. W opisie władczyni odnajdujemy nawiązania do znanego portretu carycy namalowanego przez D. Lewickiego, na którym jedną ręką rozcina ona węzeł gordyjski, drugą zaś trzyma krzyż. Symbolem panującego w kraju dostatku były leżące u jej stóp kłosy zboża, które - jak zauważa podmiot liryczny - zapewniają byt jej narodowi i są źródłem finansowania floty.

Po tej dygresji, związanej z osobami panującymi autor powraca do opisu parku, a ściślej płynącej przez niego rzeki Tyzwy. Zbudowana na niej tama tworzyła duży wodospad, na którego brzegu wznosiła się posiadłość carewicza Chlora z grotą w pobliżu rzeki, po której pływały modele statków wykonane według szkiców N. Lwowa. Widok rzeki przywodzi na myśl podmiotowi lirycznemu starcia wojenne, jakie Piotr I prowadził ze Szwedami w czasie wojny północnej (1700-1721). Stwierdza przy tym, że znajomość historii oświeca umysły młodych ludzi.

$\mathrm{Z}$ dalszego opisu ogrodu dowiadujemy się, że rozciągał się z niego widok na wiejskie chaty, lasy, pola orne, pasące się dorodne bydło. W jego wschodniej części wznosi się budynek, w którym carewicz Paweł i jego żona, Maria Fiodorowna, a także ich dzieci i opiekunki spędzały czas i czciły Katarzynę (chodzi tu o pobliski Pawłowsk).

Po zejściu z góry, na której rośnie róża bez kolców, można zachwycać się pięknem pokrytych trawą dolin, lilii rosnących na brzegach strumyków, cieniem drzew. Wszystko to przypominało swym urokiem podmiotowi lirycznemu Pola Elizejskie $^{3}$ i utwierdzało go w przekonaniu, że miejsce, w którym się znalazł jest

Pola Elizejskie - reprezentacyjna ulica Paryża, w XVIII w. modny deptak spacerowy i miejsce spotkań arystokracji. Przypomnijmy, że Dżunkowski poznał to miejsce osobiście podczas podróży po Europie. 
darem niebios. Obecność w nim pomników wielkich ludzi (np. Numy Pompiliusza, Tytusa Flawiusza, Marka Aureliusza, Aleksandra Wielkiego) dodawało mu splendoru i chwały, a także miało pokazać przyszłemu władcy Rosji właściwe wzorce, choć z bajką carycy nie miały te postaci nic wspólnego.

Ostatnim etapem wędrówki po ogrodzie byłą świątynia Flory (rzymskiej bogini kwiatów) i Pomony (rzymskiej bogini sadów, ogrodów i drzew owocowych). Altana ta nosiła nazwę „Echo”. Właśnie tutaj zwiedzający ogród mógł odpocząć, a trudy wędrówki wynagradzał mu w okresie wiosennym słodki zapach bzu

Poemat Dżunkowskiego kończy się pełną zachwytu pochwałą opisywanego miejsca, przypominającą pod względem stylu i formy panegiryczne ody Łomonosowa. Zamyka ją stwierdzenie, że nowo otwarty ogród jest szkołą dla mężczyzn.

Jak mogliśmy zauważyć, Dżunkowski w swym poemacie w oryginalny sposób połączył motywy z bajki Katarzyny II z refleksjami o charakterze opisowym i dydaktyczno-panegirycznym, typowymi dla ody pochwalnej. Poetycki opis ogrodu krajobrazowego daczy Aleksandra odzwierciedlił nową koncepcję tego gatunku, w którym architektura wpisana w bujną przyrodę otaczającego ją ogrodu i będąca sztucznym wytworem rąk ludzkich przejęła prymat nad wrażeniami, nastrojami i myślami spacerującego. „Czytanie” ogrodu otaczającego daczę Aleksandra, a nie tylko podziwianie jego piękna było możliwe dla tych, którzy znali „alfabet”, czyli treść bajki carycy oraz posiadali choćby elementarną wiedzę na temat antyczności.

Zdawałoby się zapomniana bajka carycy, jak też nieistniejące już dziś osobliwości związane parkiem i daczą Aleksandra, zostały w bardzo oryginalny sposób przypomniane współczesnym rówieśnikom Chlora. Otóż w 2011 r. po raz pierwszy młodzi ludzie mieli okazję uczestniczyć w zorganizowanym we wspomnianej już przeze mnie parkowo-pałacowej rezydencji w Pawłowsku (dziś muzeum) interaktywnym przedstawieniu dla dzieci w wieku 7-12 lat, będącym adaptacją Bajki o carewiczu Chlorze Katarzyny II. Dzieci uczestniczyły najpierw w spektaklu opartym na motywach bajki, a potem, podobnie jak carewicz Aleksander ponad dwieście lat temu uczestniczyły w wędrówce po parku w Pawłowsku w poszukiwaniu róży bez kolców. Po spektaklach, które do dziś organizowane są w tym miejscu, widzowie mogą nabyć ekskluzywne wydanie Bajki o carewiczu Chlorze ${ }^{5}$.

\section{Bibliografia}

Kaczmarczyk K. (2011), Ogród i opowieść. Przyczynek do teorii narracyjności ogrodów, [w:] „Prace Filologiczne. Literaturoznawstwo", t. LXI, Warszawa, s. 41-58.

Lichaczow D. (1991), Pozja ogrodów. O semantyce stylów ogrodowo-parkowych, tłum. J. Litwiniuk, Wrocław-Warszawa-Kraków.

Chodzi tu o bez, którego zapach sprzyjał odpoczynkowi.

http:/www.1tv.ru/news/other/174456. 
Marecki J., Rotter L. (2007), Symbolika roślin: heraldyka i symbolika chrześcijańska, Kraków. Stownik literatury polskiego Oświecenia (1996), red. T. Kostkiewiczowa, Wrocław.

Szczukin W. (2006), Mit szlacheckiego gniazda. Studium geokulturologiczne o klasycznej literaturze rosyjskiej, Kraków, s. 72-75.

Warda A. (2003), Ze studiów nad świadomościa teoretycznoliteracka w osiemnastowiecznej Rosji, Łódź.

Warda A. (2010), Горацианская формула „, иtile dulci miscere” и русская литература, [w:] Филологические традичии в современном литературном и лингвистическом образовании, т. 1, Москва, s. 17-22.

Веселова А. Ю. (2010), Садово-парковое искусство и праздничная культура в России XVIIIначала ХІХ века, [w:] Окказиональная литература в контексте проздничной культуры России XVIII века, ред. П. Бухаркин, У. Екуч, Н. Кочеткова, Санкт-Петербург, с. 356-403.

Выжевский С. (2011), Александрова дача: часть II. Архитектор Дж. Кваренги, http://dharmaser.livejournal.com/2718.html.

Джунковский С. (1793), Александрова дача, увеселительный сад Его императорского Высочества благоверного государя и Великого князя Александра Павловича, http://www. booksite.ru/usadba_new/world/fulltext/stihi/93.htm.

Краснов А. (2005), Храм Флоры и Помоны в Павловске, «Нева» № 12, s. 247-248.

Лазарчук Р. М. (2010), Официальный праздник в российской провинции последней трети XVIII века (идеология, эстетика, структура), [w:] Окказиональная литература в контексте проздничной культуры России ХVIII века, ред. П. Бухаркин, У. Екуч, Н. Кочеткова, Санкт-Петербург, с. 325-355.

Сазонова Л. И. (2006), Литературная культура России. Раннее Новое время, Москва, c. $524-557$.

Словарь русских писателей XVIII века, вып. 1: A-И, (1988), ред. А. М. Панченко, Ленинград.

\title{
Anna Warda
}

\section{The semantics of the garden in the descriptive poem Alexander's Cottage by Stiepan Dzunkowsky}

\begin{abstract}
Summary
The article is devoted to the semantics of the garden described by a Russian author of the second half of the eighteenth century - Stepan Dzunkowsky in a poem entitled Alexander's Cottage (1793). The garden described in his work was erected on the basis of an earlier narrative - Tales of Tsarevitch Chlorine, whose author was Catherine II. Dzunkowski in his poem combined in an original way the themes of the fairytale by Catherine II with descriptive and didactic reflections typical for a panegyrical ode. A poetic description of the landscaped garden of Alexander's cottage reflected a new concept of descriptive poem in which architecture and its description dominate impressions, moods and thoughts of walking across the garden. «Reading» the garden, and not just admiring it was possible for those who knew the «alphabet», i.e. the content of the fable of Tsarina and an elementary knowledge of antiquity.
\end{abstract}

